\title{
Gene expression of coffee seed oxidation and germination processes during drying
}

\author{
G.C. Santos ${ }^{1}$, E.V.R. von Pinho ${ }^{1}$ and S.D.V.F. Rosa ${ }^{2}$ \\ ${ }^{1}$ Laboratório Central de Análise de Sementes, Departamento de Agricultura, \\ Universidade Federal de Lavras, Lavras, MG, Brasil \\ ${ }^{2}$ Embrapa Café, Brasília, DF, Brasil \\ Corresponding author: S.D.V.F. da Rosa \\ E-mail: sttela.rosa@embrapa.br
}

Genet. Mol. Res. 12 (4): 6968-6982 (2013)

Received March 28, 2013

Accepted September 4, 2013

Published December 19, 2013

DOI http://dx.doi.org/10.4238/2013.December.19.16

\begin{abstract}
Coffee (Coffea arabica L.) seeds are sensitive to desiccation and oxidative stress during drying processes. We investigated the effect of drying and moisture levels on germinationrelated gene expressions associated with enzymatic systems that prevent oxidative stress in coffee seeds. Coffee seeds collected at physiological maturity were subjected to slow and quick drying to $40,30,20$, and $12 \%$ moisture levels (wet basis), and as the control, seeds without drying were used. The seeds' physiological quality was calculated as percentage of normal seedlings at 15 and 30 days, normal vigorous seedlings at 30 days, and cotyledonary leaves at 45 days. The isoenzymes esterase, catalase (CAT), peroxidase (POX), and endo- $\beta$ mannanase expressions were electrophoretically analyzed. CAT and POX expressions were analyzed using RT-qPCR with specific primers constructed from the target gene sequences from the Brazilian Coffee Genome Database. Slow drying showed better physiological quality for seeds at 40 and $12 \%$ moisture levels, while quick drying was the most effective for seeds with $20 \%$ moisture. Sensitivity to water loss was confirmed by quick drying and activation of enzymes. CAT and POX transcriptions reduced during drying. RT-qPCR revealed a
\end{abstract}


complex gene-expression pattern during the oxidative process, with high gene expression in wet seeds.

Key words: Desiccation tolerance; Isoenzyme; Endo- $\beta$-mannanase; RT-PCR; Seed aging

\section{INTRODUCTION}

Obtaining vigorous seedlings that guarantee the successful establishment of a coffee field depends on the production of high-quality seeds. This requirement is particularly important for perennial crops, because mistakes made during this initial phase risk long-term repercussions on the yield and longevity of the crop. Various factors may affect coffee seed quality. One such factor is drying, because of the sensitivity of seeds to desiccation. Coffee seeds are classified into 3 categories, recalcitrant (resistant), orthodox, and intermediate. However, existing studies about seed behavior after drying and storage have produced contradictory and inconclusive results, and primarily focus on identifying the best method of drying in relation to the final moisture level of the seeds (Rosa et al., 2011). The drying speed of the seeds also influences their physiological quality, with different studies recommending both slow drying (Brandão Júnior et al., 2002; Vieira et al., 2007) and quick drying (Rosa et al., 2005; Dussert et al., 2006) as the best drying method. Differences in the levels of tolerance to desiccation also exist among different species of Coffea (Eira et al., 1999), with the species Coffea racemosa being perceived as the most tolerant, and $C$. liberica as the most sensitive, while $C$. arabica and C. canephora are intermediate.

Recent studies observed that the loss of seed viability during drying is accompanied by an increase in reactive oxygen species (ROS) and lipid peroxidation (Oliveira et al., 2011; Park et al., 2011; Corbineau, 2012). ROS are partially reduced forms of atmospheric oxygen. These molecules are able to oxidize various cellular components, and may cause cell death (Dat et al., 2000). ROS influence DNA and RNA and, hence, the synthesis of enzymes associated with seed quality, such as superoxide dismutase, ascorbate peroxidase, dehydroascorbate reductase, monodehydroascorbate reductase, glutathione reductase, glutathione peroxidase, and guaiacol peroxidase (Corbineau, 2012).

Proteomic analyses have been used to study isoenzyme expression in investigations focusing on the loss of the physiological quality in coffee seeds. For instance, Brandão Júnior et al. (2002) observed variations in the electrophoretic patterns of free radical removing enzymes in relation to different levels of deterioration. In another study, Gomes-Junior et al. (2006) observed an increase in the enzyme activity of the oxidative process in the presence of nickel. In addition, Pertel (2004) showed that different enzymatic profiles are present in seeds subjected to physiological conditioning.

However, there is a paucity of studies about the expression of genes associated with the oxidative process during the drying of coffee seeds. However, the recent sequencing of the functional genome of coffee has made such studies possible (Caixeta, 2003; Vieira et al., 2006). Examples of known gene expressions associated with oxidative stress in seeds include genes for late embryogenesis abundant proteins (Hand et al., 2011) and enzymes like superoxide dismutase, peroxidase, catalase, dehydroascorbate reductase, monodehydroascorbate reductase, and glutathione reductase (Gomes-Junior et al., 2006). The expression of the gene that encodes 
the protein isocitrate lyase, which is an enzyme related to germination metabolism, was studied during the drying of coffee seeds, using reverse transcription (RT) and real-time polymerase chain reaction (qPCR) with specific oligonucleotides (Selmar et al., 2004). The authors found that fresh seeds contained a smaller quantity of transcripts compared to that in the dried seeds.

Therefore, it is important to investigate the expression of enzymes and certain genes related to the systems that prevent oxidative stress, along with enzymes associated with germination metabolism, in coffee seeds subjected to different drying methods and moisture levels.

\section{MATERIAL AND METHODS}

This study was developed at Laboratório Central de Análise de Sementes, Departamento de Agricultura, Universidade Federal de Lavras (UFLA), which is situated at $21^{\circ} 14^{\prime}$ latitude south and $45^{\circ} 00^{\prime}$ longitude west, and at an average altitude of $918 \mathrm{~m}$. The climate fits within the Cwb type of the Köppen classification. The annual average temperature is $19.4^{\circ} \mathrm{C}$. Rainfall primarily occurs from October to April, with an annual precipitation of $1529.7 \mathrm{~mm}$.

\section{Seed acquisition}

C. arabica L. seeds, Rubi cultivar, were collected during the cherry maturity stage, and then mechanically depulped and demucilaged by fermentation in water. After washing in running water and pre-drying to remove surface water, the seeds were subjected to slow drying in the shade and to quick drying in an experimental small scale dryer to moisture contents of $40,30,20$, and $12 \%$ wet basis (wb). Undried seeds, which had $46 \%$ moisture content, were used as a control. During slow drying, the mean speed of water loss in the seeds was $1.725 \% / \mathrm{h}$, while that during quick drying was $0.125 \% / \mathrm{h}$. The germination test was used to assess the physiological quality of seeds, while electrophoresis was used to evaluate the expression of isoenzymes in response to oxidative stress and the expression of endo- $\beta$-mannanase. Samples of all the treatments were hermetically maintained at a temperature of $-86^{\circ} \mathrm{C}$ for the gene expression analysis of the oxidative process by RT-qPCR.

\section{Evaluation of seed physiological quality}

The germination test was used to evaluate physiological quality in 4 replications of 50 seeds under 3 different conditions: 1) without parchment, 2) distributed on germitest paper, and 3) moistened with water at a quantity equivalent to 2.5 times the weight of the dry substrate. The seeds were placed in a germinator at a temperature of $30^{\circ} \mathrm{C}$ in the presence of light. Percentages were calculated for 1) normal seedlings at 15 and 30 days (Brasil, 2009), 2 ) normal vigorous seedlings at 30 days, and 3 ) the expanded cotyledonary leaves at 45 days. A normal seedling was classified as a seedling that exhibited a main root and the presence of at least 2 secondary roots, and a normal vigorous seedling was classified as that exhibiting at least $5 \mathrm{~cm}$ main root length.

The physiological quality assessment was set up in a completely randomized design, with 4 replications, in a 2 x 4 -factorial arrangement. Two drying methods (quick and slow drying) were used and 4 seed moisture levels $(40,30,20$, and 12\%). The Assistat Version 7.5 Beta 2010 software (Silva and Azevedo, 2006) was used to analyze the data, with the mean values 
being compared by the Tukey test at 5\% probability. On the same software, the Dunnett test was used to compare the mean values of the treatments against the control (without drying).

\section{Isoenzyme expression in response to oxidative stress by electrophoresis}

For the analysis of isoenzymes, samples of 50 seeds from each treatment were ground in a mill (Tecnal, model TE613/1), refrigerated at $4^{\circ} \mathrm{C}$ in the presence of polyvinylpyrrolidone and stored at $-86^{\circ} \mathrm{C}$. Protein extraction was performed by adding $280 \mathrm{~mL}$ extraction buffer $(0.2 \mathrm{M}$ Tris) to $100 \mathrm{mg}$ ground powder from the seeds. This mixture was homogenized in a vortex mixer, and then stored for $1 \mathrm{~h}$ in the refrigerator (about $4^{\circ} \mathrm{C}$ ). The samples were then centrifuged at $14,000 \mathrm{rpm}$ at $4{ }^{\circ} \mathrm{C}$ for $50 \mathrm{~min}$. Afterward, $60 \mu \mathrm{L}$ supernatant was placed on polyacrylamide gels. The gel/electrode buffer system was Tris-glycine at $\mathrm{pH}$ 8.9. Electrophoresis was performed at $150 \mathrm{~V}$ for $4 \mathrm{~h}$. Then, the gels were tested for esterase (EST), peroxidase (POX), and catalase (CAT), following the methodology of Alfenas (1998). The gel images were photographed using a 12.1-megapixel Sony digital camera with a 30-mm lens.

\section{Endo- $\beta$-mannanase isoenzyme expression}

Three hundred milliliters of extraction buffer (0.1 M HEPES, $0.5 \mathrm{M} \mathrm{NaCl}, \mathrm{pH} 8.0$, and $5 \mathrm{mg}$ ascorbic acid per $\mathrm{mL}$ buffer) was added to each microtube with $100 \mathrm{mg}$ powder from each sample. Then, the microtubes containing the samples were agitated in a vortextype mixer for $1 \mathrm{~min}$, and centrifuged at $14,000 \mathrm{rpm}$ for $30 \mathrm{~min}$ at $4^{\circ} \mathrm{C}$. The supernatant was placed on a gel containing $6 \mathrm{~mL}$ locust bean gum (LBG; Sigma), $0.24 \mathrm{~g}$ agarose (Qbiogene), $24 \mathrm{~mL}$ buffer (pH 5.0, $11 \mathrm{~mL} 1 \mathrm{M}$ citric acid, $50 \mathrm{~mL} \mathrm{Na}_{2} \mathrm{HPO}_{4}$, and $149 \mathrm{~mL}$ distilled water). The $0.5 \%$ LBG was prepared by heating the solution for $2 \mathrm{~h}$ at $80^{\circ} \mathrm{C}$, followed by cooling at ambient temperature (about $25^{\circ} \mathrm{C}$ ). The gel supports with a U-frame (Pharmacia) (glass layers) were cleaned with ethanol. This support was covered with gelbond film (Pharmacia), with the hydrophobic side being in contact with the glass first, so that the hydrophilic side remained in contact with the gel. The gelbond was covered with a second support, with the 2 supports being joined by fasteners. The gel was heated in a microwave for $1 \mathrm{~min}$, until total dissolution of the agarose. At the same time, the support was heated in a laboratory oven at $80^{\circ} \mathrm{C}$, to avoid the risk of the glass cracking because of temperature differences between the glass and the gel. The gel was applied onto the glass at ambient temperature. After solidification, the gel was stored in a refrigerator for $24 \mathrm{~h}$. The gel was pierced with a 2-mm diameter piercing tool. Then, a suction pump was used to vacuum the remaining gel through the holes. For each sample, 2 $\mu \mathrm{L}$ extract of the sample per hole was divided into 3 replicates. The gel was transferred to a dark, humid chamber of a germinator at $25^{\circ} \mathrm{C}$ for $21 \mathrm{~h}$. Subsequently, the gel was first washed with distilled water, then washed with buffer solution (gel buffer) for $30 \mathrm{~min}$, and once more with distilled water. The gel was then covered with $0.5 \%$ red Congo stain for $30 \mathrm{~min}$, and then placed in ethanol for $10 \mathrm{~min}$ to remove the stain. The ethanol was then removed by washing with distilled water. Then, $1 \mathrm{M} \mathrm{NaCl}$ was added until the formation of discolored halos could be visually observed in the holes containing the samples. The diameter of the samples was then measured in 2 directions with a caliper rule, from which the mean was calculated. To calculate enzyme activity, these values were compared with the standard curve generated by the commercial endo- $\beta$-mannanase of Aspergillus niger (Megazyme). 


\section{Gene expression of the oxidative process by RT-qPCR}

For the normalization of relative expression, endogenous controls were obtained from Barsalobres-Cavallari et al. (2009), in which the normalizing effect of these genes in coffee was tested (Table 1). To increase the reliability of the normalization, 2 endogenous controls were used: glyceraldehyde 3-phosphate dehydrogenase (GAPDH) and polyubiquitin (UBQ). The sequences of the target genes, CAT and POX (Table 1), were obtained using the Brazilian Coffee Genome Database (Banco de Dados do Genoma Café Brasileiro, CAFEST).

Table 1. Pairs of primers for the quantitative PCR tests (Universidade Federal de Lavras, Lavras, MG, 2012).

\begin{tabular}{lllc}
\hline Gene & Primer & Sequences & Efficiency (\%) \\
\hline Catalase & Forward & $5^{\prime}$-ttcgatcctgttcgtcatgct-3' & 99.94 \\
& Reverse & $5^{\prime}$-aacacacctgtcacgctttcc-3' & 96.61 \\
Peroxidase & Forward & $5^{\prime}$-ggacagtgaatatgcagcaaatct-3' & 97.51 \\
GAPDH & Reverse & $5^{\prime}$-cctggatccatttcaactatcgt-3' & 95.11 \\
& Forward & $5^{\prime}$-ttgaagggcggtgcaaa-3' & \\
UBQ & Reverse & $5^{\prime}$-aacatgggtgcatccttgct-3' & \\
& Forward & $5^{\prime}$-cgctgactacaatatccaaagga-3' & \\
\hline
\end{tabular}

For RNA extraction, the reagent RNA Plant (Invitrogen) was used. The quantity and integrity of the total RNA were evaluated by the spectrophotometer Nanovue Plus (GE Healthcare Life Sciences) and on 1.5\% agarose gel stained with ethidium bromide. The integral RNA was treated with DNAseI RNAse Free (Applied Biosystems). Subsequently, the RNA was purified using the RNeasy MinElute Cleanup Kit (Qiagen). This purification step was performed to ensure the removal of genomic DNA and salts resulting from extraction, which have previously proven to compromise PCR efficiency. Conventional PCR was carried out, followed by observation on $1.5 \%$ agarose gel, to detect the presence of genomic DNA contaminating the material.

The RT-qPCR was divided into 2 stages. RT was performed separately in aliquots of cDNA, which are conserved better than RNA. For the RT reaction, the High Capacity cDNA Reverse Transcription kit (Applied Biosystems) was used. qPCR was carried out using the reagent SYBR ${ }^{\circledR}$ Green PCR Master Mix (Applied Biosystems). All reactions were repeated 3 times, including the negative and endogenous controls. For data collection, the 7500 Real-Time PCR System v. 2.0.1 software (Applied Biosystems) was used at Laboratório Central de Análise de Sementes, Departamento de Agricultura, Universidade Federal de Lavras. After each real-time PCR, the dissociation curve was constructed for the 30 min during which the temperature increased from $60^{\circ}$ to $95^{\circ} \mathrm{C}$. From this curve, nonspecific amplifications were not observed; thus, confirming the quality of the primers and cDNAs used in the reaction.

$\Delta \Delta^{\mathrm{Ct}}$ (threshold cycle) was the relative quantification method used. For each sample, the $\mathrm{Ct}$ value was obtained from the amplification curve generated on the device. The mean $\mathrm{Ct}$ value for each sample was used to obtain the relative quantification, using GAPDH and UBQ as normalizer endogenous controls. The control seed sample (not subjected to drying) was used as a calibrator (Livak and Schmittgen, 2001). The equations used to obtain relative quantification (RQ) were as follows: i) mean Ct GENE - (mean Ct GAPDH + mean Ct UBQ) $/ 2=\Delta^{\mathrm{Ct}}$ GENE normalized; ii) Ct GENE in treatment $-\mathrm{Ct}$ GENE in calibrator $=\Delta \Delta^{\mathrm{Ct}}$; iii) $2^{-\Delta \Delta C t}=R Q$. 


\section{RESULTS}

\section{Physiological quality of the seeds}

Table 2 presents the results of the seed physiological quality evaluation. Significant interaction was observed among the drying methods and moisture content of the seeds for the percentage of normal seedlings and normal vigorous seedlings at 30 days, and of seedlings with expanded cotyledonary leaves. For normal seedlings at 15 days after sowing, the drying methods and moisture levels had no effect on the seeds. Only seeds not subjected to drying (i.e., the control) produced normal seedlings in this evaluation.

Table 2. Results of physiological evaluation of Coffea arabica L. seeds subjected to different drying methods and moisture levels (Universidade Federal de Lavras, Lavras, MG, 2012).

\begin{tabular}{|c|c|c|c|c|c|c|}
\hline \multirow[t]{3}{*}{ Moisture (\%) } & \multicolumn{3}{|c|}{ Normal seedlings at 15 days $(\%)$} & \multicolumn{3}{|c|}{ Normal seedlings at 30 days (\%) } \\
\hline & \multicolumn{3}{|c|}{ Drying method } & \multicolumn{3}{|c|}{ Drying method } \\
\hline & Quick & & Slow & Quick & & Slow \\
\hline 40 & $0^{*}$ & & $0^{*}$ & $83^{\mathrm{LB}}$ & & $91^{\mathrm{aA}}$ \\
\hline 30 & $0^{*}$ & & $0^{*}$ & $89^{\mathrm{aAB}}$ & & $89^{\mathrm{aA}}$ \\
\hline 20 & $0^{*}$ & & $0^{*}$ & $92^{\mathrm{aA}}$ & & $78^{\mathrm{bB}}$ \\
\hline 12 & $0^{*}$ & & $0^{*}$ & $74^{\mathrm{bC} *}$ & & $87^{\mathrm{aA}}$ \\
\hline 46 (Control) & & 9 & & & 85 & \\
\hline CV $(\%)$ & & 5.71 & & & 5.11 & \\
\hline \multirow[t]{3}{*}{ Moisture (\%) } & \multicolumn{3}{|c|}{ Normal vigorous seedlings at 30 days (\%) } & \multicolumn{3}{|c|}{ Seedlings with expanded cotyledonary leaves at 45 days (\%) } \\
\hline & \multicolumn{3}{|c|}{ Drying method } & \multicolumn{3}{|c|}{ Drying method } \\
\hline & Quick & & Slow & Quick & & Slow \\
\hline 40 & $14^{\mathrm{bB} *}$ & & $29^{\mathrm{aAB}}$ & $16^{\mathrm{bAB} *}$ & & $30^{\mathrm{aA}}$ \\
\hline 30 & $15^{\mathrm{bB}} *$ & & $34^{\mathrm{aA}}$ & $19^{\mathrm{aA} *}$ & & $14^{\mathrm{aB} *}$ \\
\hline 20 & $57^{\mathrm{aA} *}$ & & $21^{\mathrm{bB}}$ & $16^{\mathrm{aAB} *}$ & & $12^{\mathrm{aB} *}$ \\
\hline & $12^{\mathrm{bB} *}$ & & $21^{\mathrm{aB}}$ & $7 \mathrm{aB} *$ & & $\mathrm{l}^{\mathrm{aC} *}$ \\
\hline 46 (Control) & & 28 & & & 41 & \\
\hline CV $(\%)$ & & 22.58 & & & 14.99 & \\
\hline
\end{tabular}

Mean values followed by the same superscript small letters in the lines and capital letters in the columns did not differ among themselves at the $5 \%$ level of probability by the Tukey test. *Mean values differed from the control at the $5 \%$ level of probability by the Dunnett test.

At 30 days, the two drying methods had different effects on normal seeds (Table 2). In general, drying reduced the physiological quality of the seeds, with more number of normal plants being obtained from seeds with an intermediate moisture level, when subjected to quick drying. In contrast, under slow drying, fewer normal plants were obtained in seeds with $20 \%$ $\mathrm{wb}$ moisture level. Slow drying increased the percentage of normal plants obtained from seeds with 40,30 , and $12 \%$ wb moisture levels. In comparison, quick drying increased the number of normal plants obtained from seeds with 30 and $20 \% \mathrm{wb}$ moisture levels. The physiological quality of the seeds with $12 \%$ wb moisture was less affected by slow drying compared to quick drying. Based on the percentage of normal seedlings obtained at 30 days, only the seeds with $12 \% \mathrm{wb}$ moisture level subjected to quick drying exhibited inferior performance compared to the control (with $46 \%$ wb moisture).

The percentages of normal vigorous seedlings and of seedlings with expanded cotyledonal leaves at 45 days were indicative of seed vigor, because stricter criteria are used com- 
pared to the criteria used to evaluate normal plants at 30 days. The physiological quality of the assessed variables for the treatments is presented in Table 2. For normal vigorous seedlings at 30 days, seeds subjected to quick drying produced seedlings of lower vigor compared to the control (46\% wb moisture level, not subjected to drying); however, seeds subject to quick drying to $20 \% \mathrm{wb}$ moisture level also produced low vigor seedlings. For slow drying, the highest seedling vigor was observed in seeds with $30 \% \mathrm{wb}$ moisture level (Table 2). The physiological quality of seeds was worse under lower moisture contents, and mainly after slower drying.

For seedlings with expanded cotyledonal leaves at 45 days, the coffee seeds lost vigor under all drying treatments compared to the control, except for seeds subjected to slow drying to $40 \%$ wb moisture level. In addition, under both drying methods, lower seed moisture levels resulted in lower seedling vigor at the opening of the cotyledons. Coffee seeds have leafy and photosynthetic type cotyledons, which accelerates seedling development (Ferreira and Borghetti, 2004). Therefore, this variable is important for evaluating the loss of vigor in coffee seeds, despite the extended period of evaluation that is required to obtain results.

\section{Isoenzyme expression by electrophoresis}

The activity of endo- $\beta$-mannanase is shown in Figure 1 . The highest activity levels of this enzyme were recorded in the quick drying treatment to $20 \% \mathrm{wb}$ moisture level and the slow drying treatment to $30 \% \mathrm{wb}$ (Figure 1). Greater seed vigor was also observed in these treatments from normal vigorous seedlings at 30 days (Table 2).

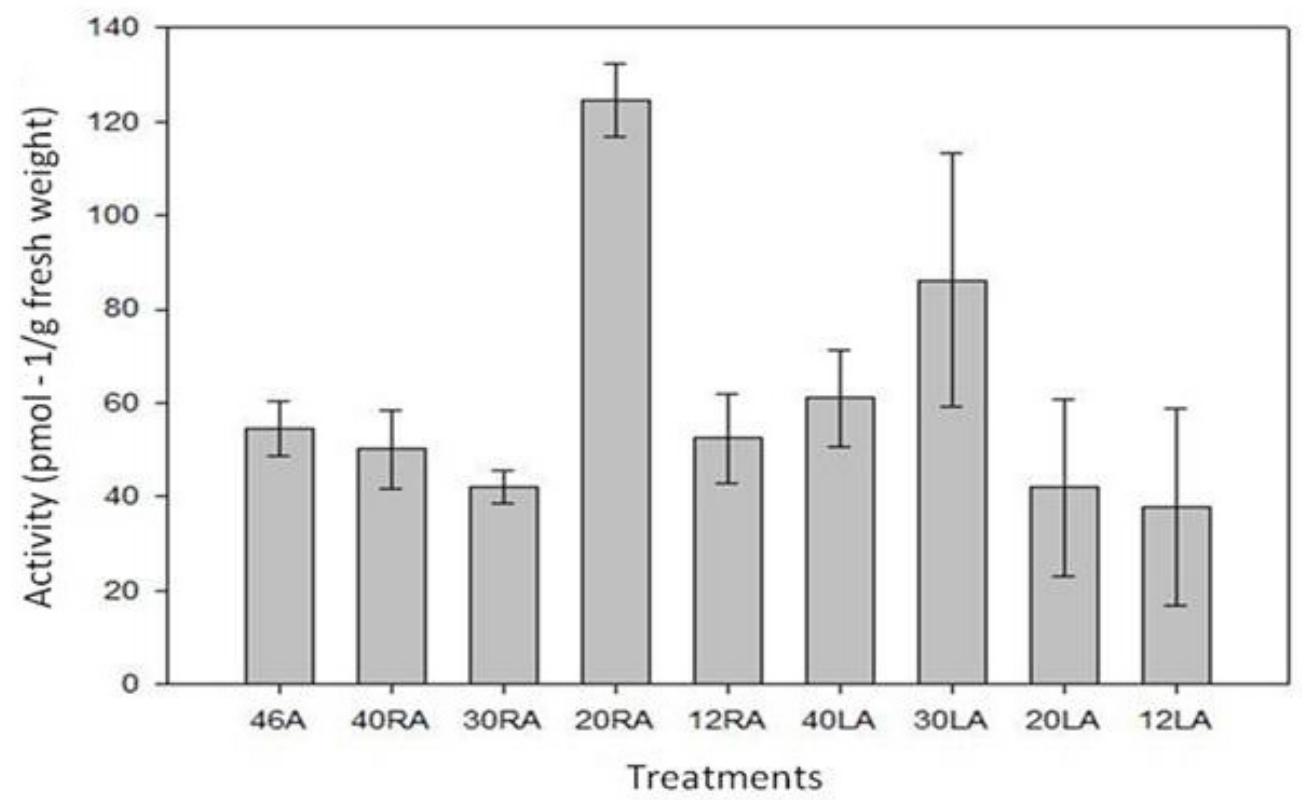

Figure 1. Activity of the endo- $\beta$-mannanase enzyme in Coffea arabica L. seeds (A) subjected to quick (R) and slow (L) drying to moisture levels of 40,30, 20 and 12\% wet basis; and control without drying, at 46\% wet basis (Universidade Federal de Lavras, Lavras, MG, 2012). 
Figure 2 shows that the expression of EST, CAT, and POX enzymes increases with increased drying. The activity of these enzymes increases in seeds with higher moisture content under slow drying compared to quick drying. EST enzyme activity was highest in seeds with $20 \% \mathrm{wb}$ moisture during slow drying and in seeds with $30 \% \mathrm{wb}$ during quick drying. In seeds not subjected to drying (control, 46\%), EST and POX enzyme activity was low. As observed for EST, CAT and POX were also activated in seeds with greater moisture content (Figure $2 \mathrm{~b}, \mathrm{c})$. CAT removes hydrogen peroxide, which is an extremely toxic compound. Hydrogen peroxide is produced in the beta-oxidation of fatty acids. EST is an indicator of this metabolism process (Mittler, 2002).

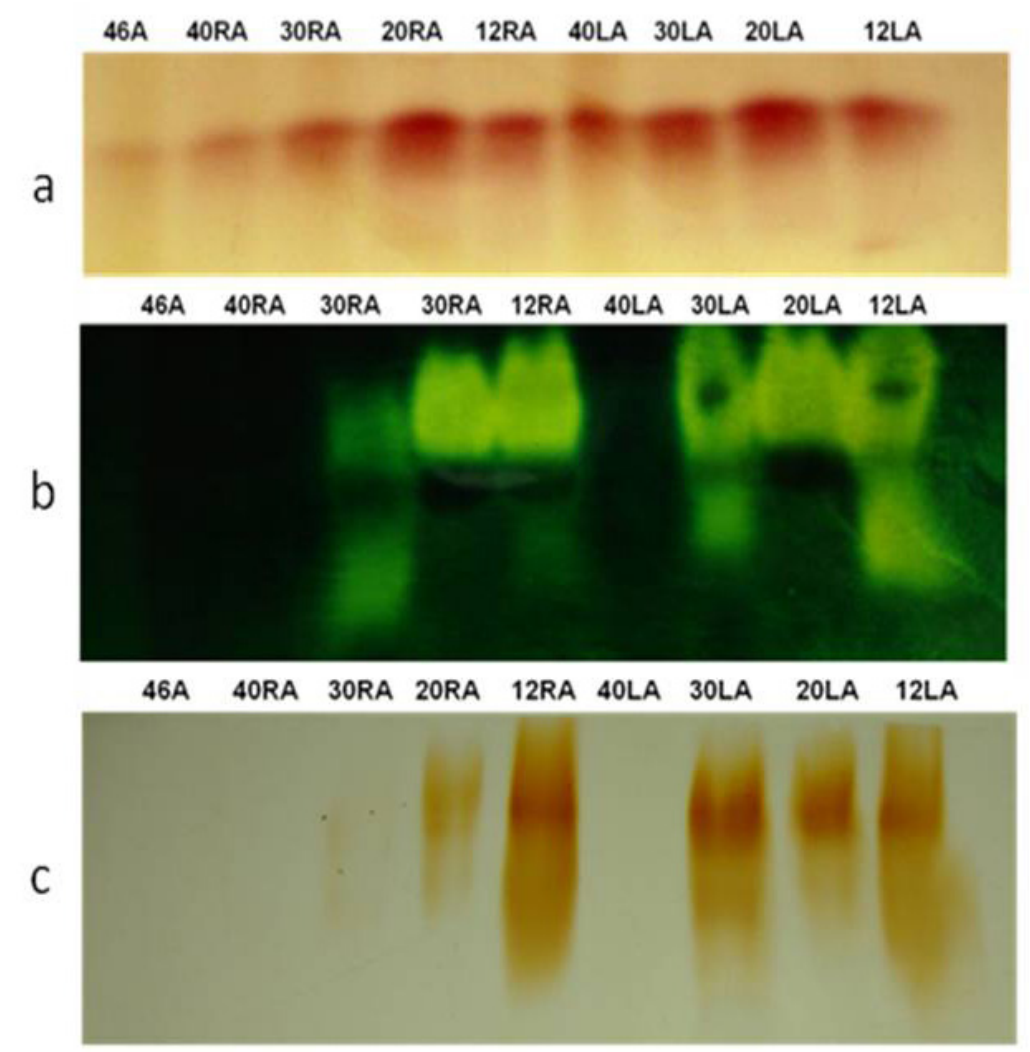

Figure 2. Isoenzymatic patterns of esterase (a), catalase (b) and peroxidase (c) in Coffea arabica L. seeds (A), subjected to quick (R) and slow (L) drying to moisture levels of 40,30, 20 and 12\% wet basis; and control without drying at $46 \%$ wet basis (Universidade Federal de Lavras, Lavras, MG, 2012).

\section{Gene expression of the oxidative process by RT-qPCR}

As described in the methodology, the target sequences were analyzed by means of bioinformatics to confirm their identity. This strategy was necessary because CAFEST does not yet have a completely annotated set of expressed sequence tags. The results of the identity analysis are presented in Table 3. The E-value was satisfactory for the 2 target sequences, confirmed by both BLASTp and Pfam. 
Table 3. Result of BLASTp and Pfam for the sequences translated in silicon of the target genes (Universidade Federal de Lavras, Lavras, MG, 2012).

\begin{tabular}{lllcc}
\hline Target gene & NCBI accession No. & Probable function NCBI & E-value BLASTp & E-value Pfam \\
\hline Catalase & P49317.1 & Catalase 3 & 0.0 & $5.8 \mathrm{e}-71$ \\
Peroxidase & AAU04879.1 & Peroxidase a & 0.0 & $4.3 \mathrm{e}-179$ \\
\hline
\end{tabular}

The expressed sequence tag of CAT was shown on silicon to identify the protein domains. The analysis of domains conserved in the target sequences (query sequence) showed the presence of typical domains of the genes of interest. The analysis of protein domains was also carried out to confer the annotation of the translated peroxidase sequence.

Superior values of expression of the CAT and POX transcripts were observed in the seeds of the control in relation to the other treatments (Figure 3). The control was used as a reference sample for the normalization of the relative expression. Salmona et al. (2008) also observed an increase in the relative expression of mRNA catalase at the fresh cherry stage. The authors observed that transcripts related to the processes of germination and the acquisition of tolerance to desiccation accumulate during the final stages of coffee seed development. The accumulation of these transcripts allows the seed cells respond more rapidly to future physiological conditions, such as stress through desiccation (Soeda et al., 2005). Beyond this stage, the respective proteins produced by these accumulated genes were not observed, probably because their presence would cause the seed to become nonviable or because they unnecessarily utilize metabolic energy. The results observed by Soeda et al. (2005) might also help explain why catalase and peroxidase isoenzyme was not observed in the current study (Figure 2). This result is compatible with current knowledge about the dogma of molecular biology, which indicates that the presence of RNA does not necessarily mean the obligatory presence of the protein product.

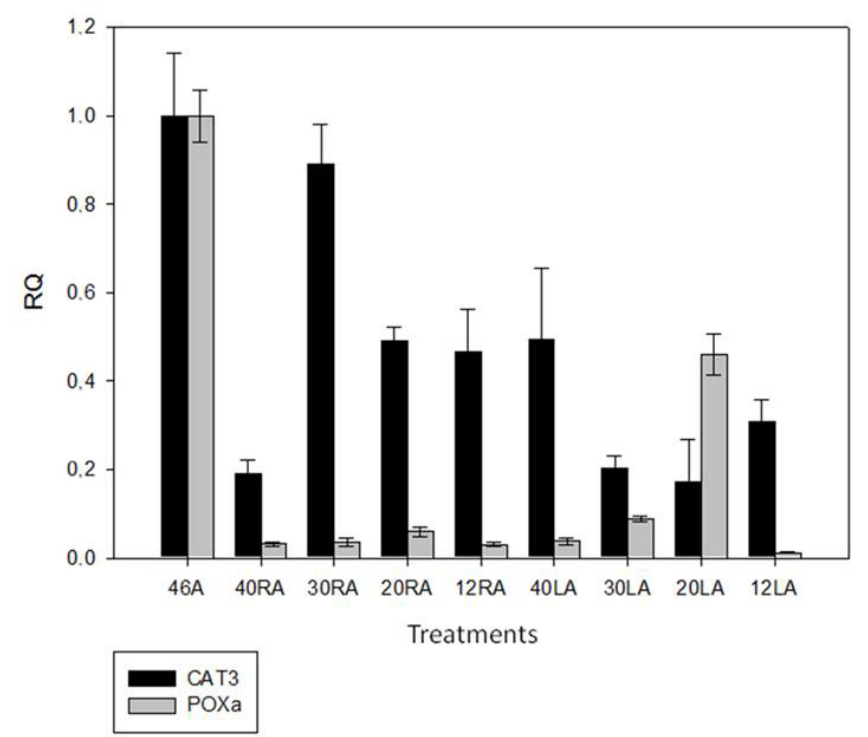

Figure 3. Gene expression of catalase 3 (CAT3) and peroxidase a (POXa) in Coffea arabica L. seeds (A), subjected to quick (R) and slow (L) drying to moisture levels of 40,30, 20 and 12\% wet basis; and control without drying at $46 \%$ wet basis (Universidade Federal de Lavras, Lavras, MG, 2012). RQ = relative quantification. 
Different mechanisms regulate gene expression between the RNA and its protein product, which might be used in relation to the needs of the cell (Carrington and Ambros, 2003). The gene expression levels of seeds subjected to the drying treatments were lower compared to the control (Figure 3). These reduced levels might represent the usage of the initial stock of transcripts when the seeds were subjected to the different treatments, when these transcripts were necessary. The degradation hypothesis was dismissed because of the good results observed on the acrylamide gel and the high efficiency of the primers obtained from qPCR.

The reorganization of the expression of these genes was also observed, in which, either part of the original stock of the transcripts of these genes was replaced or expression was lost again (Figure 3). The stimuli that led to this reorganization were not detected in the present study; however, it was probably caused by a combination of the effects of the drying rate, moisture level, ROS content, and non-enzymatic defense mechanisms, among others. This phenomenon happens because seed tolerance to desiccation is a feature of quantitative genetic control (Brandão Júnior et al., 2002).

CAT expression increased in seeds with $30 \%$ wb moisture level during quick drying, and decreased for all subsequent moisture levels. CAT expression resumed at a reduced level under slow drying. In addition, while CAT expression also reduced in seeds with intermediate moisture levels, it increased in seeds with $12 \%$ wb moisture level (Figure 2). This difference might be associated with the different drying rates in the 2 methods (Rosa et al., 2005). CAT gene expression did not appear to have a clear relationship with physiological quality.

POX gene expression was lower in seeds subjected to drying compared to controls (Figure 3). In addition, the reorganization of the expression of this enzyme was observed, resulting in an increase in its expression in seeds with $20 \% \mathrm{wb}$ moisture level that were subjected to slow drying. This result indicates that there was an increase in stress during slow drying to $20 \% \mathrm{wb}$ moisture level.

\section{DISCUSSION}

The germination results observed in this study may be explained based on the occurrence of damage to the cellular membrane, caused by the interaction of the drying method and moisture levels after this process has taken place. Saath et al. (2010) analyzed the effect of different drying methods on the maintenance of the integrity of the cell wall and of the plasmatic membrane in $C$. arabica L. seeds, to determine the conditions and the time at which microscopic ruptures occur. These authors observed that slow drying treatments caused no damage to the membrane at moisture levels of 11 and $40 \% \mathrm{wb}$. These findings support the germination results obtained during slow drying in the current study (Table 2). Saath et al. (2010) observed that quick drying caused more damage to seeds at moisture levels of $20-30 \% \mathrm{wb}$. However, the authors used different quick drying methods (2 times higher temperature) to those used in the current study, which may explain the differences in the results obtained.

In the current study, the heat of drying air might have activated the germination process, because a reduction in the water potential of live coffee seeds induces large metabolic responses to water stress. Kramer et al. (2010) studied gamma-aminobutyric acid, dehydrin, and isocitrate lyase expression. Isocitrate lyase expression peaked at a range of 50-40\% wb moisture level, indicating the onset of germination metabolism; yet, its expression declined at a range of $40-30 \% \mathrm{wb}$, when dehydrins and GABA expressions peaked, which indicates water 
stress. During germination, the synthesis or activation of enzymes responsible for the degradation of the seed reserves is initiated. Among these enzymes, EST is involved in the metabolic processes of plant germination and maturation. These enzymes are expressed constitutively in the seeds during germination; consequently, the reserves are released for the growth of the embryo (Subramani et al., 2011). Since EST might also be involved in seed-reserve degradation, another enzyme endo- $\beta$-mannanase involved in germination was analyzed. This enzyme is involved in the mobilization process of endosperm reserves, making them available for seedling growth and development.

An increase in the expression of endo- $\beta$-mannanase was observed in seeds with moisture levels of 20 and $30 \% \mathrm{wb}$ that were subjected to quick and slow drying, respectively (Figure 1). At these intermediate ranges of moisture level, an increase was observed in the germination values for both drying methods (Table 2 ). Endo- $\beta$-mannanase activity is associated with the mobilization of endosperm reserves, making these reserves available for seedling growth and development (Iglesias-Fernandez et al., 2011). The cells that cover the radicle exhibit mechanical resistance to cellular elongation during germination. This resistance is reduced by the enzymatic hydrolysis of the cell wall of endosperm cells, which are rich in mannans. In contrast, the cell walls of embryonic cells are not rich in mannans; therefore, they are not digested by endo- $\beta$-mannanase. In this way, cellular elongation potential overcomes the physical resistance of the endosperm during germination (Iglesias-Fernandez et al., 2011).

Early germination is avoided when the seed is in the fruit, mainly because of the effect of abscisic acid (ABA) and the osmotic potential of the fresh fruit environment. During the process of fruit development, the endocarp, which is rich in ABA, is removed and the seed is hydrated and heated, inducing the onset of germination (Bytof et al., 2007). These authors also observed an increase in the expression of isocitrate lyase and beta-tubulin genes, which are related to the metabolic process of germination during coffee seed processing.

In the current study, the moisture level present in the seeds after the drying process was also studied, because of its importance for the physiological quality of coffee seeds. Brandão Júnior et al. (2002) studied variations in germination under extreme humidity and the effect of drying on C. arabica seeds of the Acaiá Cerrado cultivar. The authors did not observe any significant difference in germination and vigor of fresh seeds $(50 \% \mathrm{wb})$ with those subjected to quick drying (15\% wb). Rosa et al. (2005) also observed that moisture level affects the physiological quality of $C$. canephora Pierre seeds in the radicle protrusion variable soon after drying; however, interaction with the storage effect is necessary to cause significant differences in the germination variable at 30 days. These differences might be explained by the different genetic and methodological techniques used in the current study compared to those of Rosa et al. (2005).

During the germination process, cellular respiration increases to generate energy. Cellular respiration damages mitochondria, in addition to increasing oxidative stress and causing the aging of tissues (Barreiros et al., 2006). To evaluate the activation of ROS controlling enzymes in the 2 drying processes, the expression of CAT and POX enzymes were evaluated (Figure 2b,c). The CAT isoenzyme activated seeds with $12-30 \% \mathrm{wb}$ humidity in both the drying methods (Figure 2b). Leymarie et al. (2012) also found that CAT was not active before the activation of germination metabolism in Arabidopsis thaliana seeds. The CAT enzyme is activated by an increase in the concentration of hydrogen peroxide, which is produced through cellular respiration and through the beta-oxidation of fatty acids, to combat aging (Mittler, 
2002). The highest CAT gene expression was observed in the control seeds, which were not subjected to drying (Figure 3). However, CAT enzyme transcription was also activated during the pre-drying processing of the seeds (Kibinza et al., 2011). Salmona et al. (2008) also observed an increase in the relative expression of CAT mRNA during the fresh cherry stage.

The expression of different genes cannot be compared quantitatively through realtime PCR. This is because the gene expression of each sample is normalized with the expression of the same gene in the reference sample. This difference may be observed in the expression of the reference sample (the control), where both have a relative expression equal to one. Quantitative comparisons among the relative expressions of different genes may only be made in absolute quantification; however, the patterns of expression may be compared (Wong and Medrano, 2005). The expression pattern of the POX target differed to the observed pattern for CAT, with the exception of more transcripts being present in the control sample (Figure 3).

These fluctuations in the levels of the CAT and POX genes (Figure 3) might be related to the necessity of maintaining ROS at adequate levels for cellular survival. Cellular biology studies have clearly described the beneficial functions of hydrogen peroxide to the cell, beyond causing oxidative stress. One of these beneficial functions is stopping the cellular cycle during DNA repair after certain types of stress and aging. Under certain types of stress, mutagenesis of the genetic material occurs, which must be repaired before the cellular cycle proceeds. The excessive removal of hydrogen peroxide free radicals might reduce this inhibition of the cellular cycle, which would then resume its course, even with damaged DNA. With this refined regulation, the cells of the coffee seeds are probably able to combat oxidative stress, without interfering in the regulation of the cellular cycle (Takahashi et al., 2007). The absence of CAT might result in the inactivation of the superoxide dismutase enzyme, which is another enzyme related to oxidative stress (Fridovich, 1995); therefore, its expression must be maintained at adequate levels.

As mentioned in the results for endo- $\beta$-mannanase (Figure 1), post-harvest processing might activate the enzymatic mechanisms of germination in situations of oxidative stress. In other words, the cells of the embryo receive environmental stimuli that lead to cellular growth at a time during which mutations might be occurring in important genes. The drying process causes water and oxidative stress, which generate mutagenic ROS (Dussert et al., 2006). If the cell continues with cell division, some mutations will be established in a definitive manner. Therefore, the hypothesis of refined control of cell division using an adequate concentration of hydrogen peroxide might explain the reduced expression levels of these enzymes, which remove this ROS.

Tolerance to oxidative stress is clearly quantitative, making it difficult to study. This issue might explain why gene expression observed in this study did not clearly follow the physiological quality standard. For example, in the ascorbate glutathione cycle, hydrogen peroxide is removed in the presence of ascorbate peroxidase, monodehydroascorbate reductase, dehydroascorbate reductase, and glutathione reductase (Foyer et al., 1997), rather than CAT. In addition, various non-enzymatic antioxidants are present, such as cysteine, mannitol, carotenoids, ascorbic acid, and glutathione (Mittler, 2002). An alternative strategy would be to try to obtain degenerated primers that anneal to all of the isoforms of a given enzymatic class. It is a difficult task, because there are numerous enzymes in a single class. Another strategy would be to evaluate the levels of gene expression for transcription factors linked to stress. These transcription factors control the expression of various genes with corresponding functions at the same time. 
The results of real-time PCR for the expressed sequence tags of CAT and POX (Figure 3) did not follow the pattern found in the respective isoenzymatic analyses. The greatest values of relative expression were observed in the control, with subsequent expression levels declining for both genes. At first, this observation might seem incoherent; however, the results obtained for the isoenzymes (Figure 2) represent the activity of all enzymes that react with the same substrate (Stryer et al., 2004). In contrast, in real-time PCR, a single expressed sequence tag might be separated, as shown by the bioinformatic results and dissociation curve of the product of reaction. The presence of a transcript does not imply that the same proportion of the respective polypeptide product is being translated, and even if it is being translated proportionally, this does not imply that the enzymes are activated and functional. Further, these transcripts represent the known regulation mechanisms of gene expression, which have various levels, from the DNA to the phenotype, strictly speaking. Any metallic ion, especially copper (II) and iron (II), might act as a non-competitive inhibitor of CAT.

Seed cells prepare to respond more rapidly to future adverse physiological conditions (such as stress through desiccation) by accumulating certain transcribed genes (Soeda et al., 2005). Analysis of gene expression in the treatments that underwent both slow and quick drying, revealed the complex pattern of CAT and POX gene expression (Figure 3). Differences in expression time in the embryo and in the endosperm might explain these differences, as observed in previous studies on coffee seeds during processing (Dussert et al., 2006; Kramer et al., 2010). An alternative for refining the study of gene expression in seeds is to separately extract the RNA from the embryo and endosperm. However, it is difficult to separate the embryo and endosperm in dehydrated seeds.

Efforts to improve the quality of coffee seeds subjected to drying should probably focus on sources of variation that affect the preservation of the membrane systems. For instance, low seed moisture levels 1) cause damage through imbibition and leaching of nutrients and 2) disorganize metabolism processes that combat oxidative and water stresses. In addition, high drying temperature and moisture levels disorganize the metabolism of germination, in addition to causing the degradation of the endosperm and the membranes. The combination of these sources of variation, along with the different methodologies and different genotypes, reflects the diversity of results found in the literature.

Slow drying tends to be preferentially used for production of coffee seeds. Nevertheless, during slow drying, the seeds may remain in a particular state of hydration, resulting in the defense mechanisms protecting against damage from desiccation being insufficient (Rosa et al., 2005). From a physiological perspective, the effect of the drying method depends on the moisture level; for instance, slow drying facilitates the greater seed germination of seeds with $12 \% \mathrm{wb}$ moisture level compared to quick drying. Biochemically, sensitivity to drying was observed, leading to the activation of germination enzymes, membrane degradation, and combat of hydrogen peroxide, primarily for seeds of $30-12 \%$ wb moisture level. RT-qPCR analyses detected a complex pattern of CAT and POX expression, in which the control showed greatest expression. There was reduction in the expression levels of CAT and POX enzyme transcripts with the increased drying of $C$. arabica seeds. The expression patterns of POX and CAT enzymes also differed, despite both being associated with oxidative stress responses. CAT and POX genes are associated with the oxidative process, and their expression levels were affected by both the drying method and moisture level.

This study showed that the slow drying method caused a critical reduction in the physiological quality of coffee seeds (Table 2). These results clarify the importance of con- 
ducting studies to improve post-harvest processing, drying, and storage of coffee seeds, to obtain vigorous seedlings.

\section{ACKNOWLEDGMENTS}

Research supported by the following Brazilian government entities: CAPES, CNPq, Embrapa, FAPEMIG, and UFLA.

\section{REFERENCES}

Alfenas AC (1998). Eletroforese de Isoenzimas e Proteínas Afins: Fundamentos e Aplicações em Plantas e Microrganismos. 1 st edn. Editora UFV, Viçosa.

Barreiros ALBS, David JM and David JP (2006). Estresse oxidativo: relação entre geração de espécies reativas e defesa do organismo. Quim. Nova 29: 113-123.

Barsalobres-Cavallari CF, Severino FE, Maluf MP and Maia IG (2009). Identification of suitable internal control genes for expression studies in Coffea arabica under different experimental conditions. BMC Mol. Biol. 10: 1.

Brandão Júnior DS, Vieira MGGC, Guimarães RM and Hilhorst HWM (2002). Aquisição da tolerância à dessecação nos diferentes estádios de desenvolvimento de sementes de cafeeiro (Coffea arabica L.). Cienc. Agrotec. 4: 673-681.

BRASIL (Ministério da Agricultura e Reforma Agrária) (2009). Regras para Análise de Sementes. Secretaria Nacional de Defesa Agropecuária, Brasília.

Bytof G, Knopp SE, Kramer D, Breitenstein B, et al. (2007). Transient occurrence of seed germination processes during coffee post-harvest treatment. Ann. Bot. 100: 61-66.

Caixeta ET (2003). Avanços Tecnológicos em Biologia Molecular: Projeto Genoma no Melhoramento de Plantas. In: Produção Integrada de Café Editora UFV, Viçosa, 223-246.

Carrington JC and Ambros V (2003). Role of microRNAs in plant and animal development. Science 301: 336-338.

Corbineau F (2012). Markers of seed quality: from present to future. Seed Sci. Res. 22: 61-68.

Dat J, Vandenabeele S, Vranova E, Van Montagu M, et al. (2000). Dual action of the active oxygen species during plant stress responses. Cell. Mol. Life Sci. 57: 779-795.

Dussert S, Davey MW, Laffargue A, Doulbeau S, et al. (2006). Oxidative stress, phospholipid loss and lipid hydrolysis during drying and storage of intermediate seeds. Physiol. Plant 127: 192-204.

Eira MTS, Walters C, Caldas LS, Fazuoli LC, et al. (1999). Tolerance of Coffea spp. seeds to desiccation and low temperature. Rev. Braz. Fisiol. Veg. 11: 97-105.

Ferreira AG and Borghetti F (2004). Germinação: do Básico ao Aplicado. 1st edn. Artmed, Porto Alegre.

Foyer CH, Lopes-Delgado H, Dat JF and Scott IM (1997). Hydrogen peroxide and glutathione-associated mechanisms of acclamatory stress tolerance and signaling. Physiol. Plant 100: 241-254.

Fridovich I (1995). Superoxide radical and superoxide dismutases. Annu. Rev. Biochem. 64: 97-112.

Gomes-Junior RA, Moldes CA, Delite FS, Gratao PL, et al. (2006). Nickel elicits a fast antioxidant response in Coffea arabica cells. Plant Physiol. Biochem. 44: 420-429.

Hand SC, Menze MA, Toner M, Boswell L, et al. (2011). LEA proteins during water stress: not just for plants anymore. Annu. Rev. Physiol. 73: 115-134.

Iglesias-Fernandez R, Rodriguez-Gacio MC, Barrero-Sicilia C, Carbonero P, et al. (2011). Molecular analysis of endo$\beta$-mannanase genes upon seed imbibition suggest a cross-talk between radicle and micropylar endosperm during germination of Arabidopsis thaliana. Plant Signal. Behav. 6: 80-82.

Kibinza S, Bazin J, Bailly C, Farrant JM, et al. (2011). Catalase is a key enzyme in seed recovery from ageing during priming. Plant Sci. 181: 309-315.

Kramer D, Breitenstein B, Kleinwächter M and Selmar D (2010). Stress metabolism ib green coffee beans (Coffea arabica L.): expression of dehydrins and accumulation of GABA during drying. Plant Cell Physiol. 51: 546-553.

Leymarie J, Vitkauskaite G, Hoang HH, Gendreau E, et al. (2012). Role of reactive oxygen species in the regulation of Arabidopsis seed dormancy. Plant Cell Physiol. 53: 96-106.

Livak KJ and Schmittgen TD (2001). Analysis of relative gene expression data using real-time quantitative PCR and the $2^{-\Delta \Delta C t}$ method. Methods 25: 402-408.

Mittler R (2002). Oxidative stress, antioxidants and stress tolerance. Trends Plant Sci. 7: 405-410.

Oliveira AB, Gomes-Filho E, Enéas-Filho J, Prisco JT, et al. (2011). Seed priming effects on growth, lipid peroxidation, 
and activity of ROS scavenging enzymes in NaCl-stressed sorghum seedlings from aged seeds. J. Plant Interact. 7: 151-159.

Park JJ, Yi J, Yoon J, Cho LH, et al. (2011). OsPUB15, an E3 ubiquitin ligase, functions to reduce cellular oxidative stress during seedling establishment. Plant J. 65: 194-205.

Pertel J (2004). Alterações Fisiológicas e Bioquímicas Durante o Envelhecimento Natural e Artificial de Sementes de Café (Coffea arabica L.). Doctoral thesis, UFV, Viçosa.

Rosa SDVF, Junior DSB, Von Pinho EVR, Veiga AD, et al. (2005). Effects of different drying rates on the physiological quality of Coffea canephora pierre seeds. Braz. J. Plant Physiol. 17: 199-205.

Rosa SDVF, Carvalho AM, McDonald MB, Von Pinho VER, et al. (2011). The effect of storage conditions on coffee seed and seedling quality. Seed Sci. Technol. 39: 151-164.

Saath R, Borém FM, Alves E, Taveira JHS, et al. (2010). Scannig electron microscopy of the endosperm of coffee (Coffea arabica L.) during the drying process. Cienc. Agrotec. 34: 196-203.

Salmona J, Dussert S, Descroix F, de Kochko A, et al. (2008). Deciphering transcriptional networks that govern Coffea arabica seed development using combined cDNA array and real-time RT-PCR approaches. Plant Mol. Biol. 66: 105-124.

Selmar D, Bytof G, Knopp SE, Bradbury A, et al. (2004). Biochemical Insights into Coffee Processing: Quality and Nature of Green Coffee are Interconnected with an Active Seed Metabolism. In: International Conference in Coffee Science, 20th. ASIC, 2004. 1. CD-ROM, Bangladore.

Silva FAS and Azevedo CAV (2006). A New Version of the Assistat-Statistical Assistance Software. In: World Congress on Computers in Agriculture 4 American Society of Agricultural and Biological Engineers, Orlando, 393-396.

Soeda Y, Konings MC, Vorst O, van Houwelingen AM, et al. (2005). Gene expression programs during Brassica oleracea seed maturation, osmopriming, and germination are indicators of progression of the germination process and the stress tolerance level. Plant Physiol. 137: 354-368.

Stryer L, Tymoczko JL and Berg JM (2004). Bioquímica. 5. Guanabara, Rio de Janeiro.

Subramani T, Manjunath KC, Chandrashekharaiah KS, Swamy NR, et al. (2011). Variations in the esterase activity during the germination period of Jatropha curcas seeds. J. Phytol. 3: 1-3.

Takahashi A, Ohtani N and Hara E (2007). Irreversibility of cellular senescence: dual roles of p16INK4a/Rb-pathway in cell cycle control. Cell Div. 2: 10.

Vieira AR, Oliveira JA, Guimarães RM, Pereira CE, et al. (2007). Armazenamento de sementes de cafeeiro: ambientes e métodos de secagem. Rev. Bras. Sementes 29: 76-82.

Vieira LGE, Andrade AC, Colombo CA, Moraes AHAM, et al. (2006). Brazilian coffee genome project: an EST-based genomic resource. Braz. J. Plant Physiol. 18: 95-108.

Wong ML and Medrano JF (2005). Real-time PCR for mRNA quantitation. Biotechniques 39: 75-85. 